\title{
An Economic Theory of Church Strictness*
}

\author{
Pedro Pita Barros ${ }^{\dagger}$ \\ Universidade Nova de Lisboa \\ Centre for Economic Policy Research, London \\ Nuno Garoupa $a^{\ddagger}$ \\ Universitat Pompeu Fabra
}

This version: August, 2001

\footnotetext{
*We are grateful to Tim Besley, Ricardo Ferreira, Laurence Iannaccone, two referees, and the Editor, Cristopher Bliss for helpful suggestions. The usual disclaimer applies.

${ }^{\dagger}$ Faculdade de Economia, Universidade Nova de Lisboa, Travessa Estevao Pinto, P1099-032 Lisboa, Portugal, ppbarros@fe.unl.pt

${ }^{\ddagger}$ Department d'Economia i Empresa, Universitat Pompeu Fabra, Ramon Trias Fargas 25-27, 08005 Barcelona, Spain, nuno.garoupa@econ.upf.es
} 


\begin{abstract}
This paper makes several contributions to the growing literature on the economics of religion. First, we explicitly introduce spatiallocation models into the economics of religion. Second, we offer a new explanation for the observed tendency of state (monopoly) churches to locate toward the "low-tension" end of the "strictness continuum" (in a one-dimensional product space): This result is obtained through the conjunction of "benevolent preferences" (denominations care about the aggregate utility of members) and asymmetric costs of going to a more or less strict church than one prefers.

We also derive implications regarding the relationship between religious strictness and membership. The driving forces of our analysis, religious market interactions and asymmetric costs of membership, highlight new explanations for some well-established stylized facts. The analysis opens the way to new empirical tests, aimed at confronting the implications of our model against more traditional explanations.
\end{abstract}

Key words: location theory, economics of religion JEL classification: Z 


\section{Introduction}

The literature of economic analysis of religion is very scarce. Armed with the tools of economic theory, the economics of religion attempts to address issues that were previously confined to other social sciences: The determinants of religious belief and behavior, the nature and behavior of religious institutions, and the economic impact of religion. The recent Journal of Institutional and Theoretical Economics issue on economics of religion, edited by Schlicht (1997), is clear evidence of a growing interest in these problems within economics. ${ }^{1}$

A relevant question and possibly an explanation for the slow start of the economics of religion is the controversy over the importance of religion in a world characterized by the modern life style. On one hand, many authors talk about the secularization movement and the decline of religion (Martin, 1978). The collapse of religious practice in both Ireland and Poland in the 90s seems to be evidence of that. However, Iannaccone (1994b, 1995b) having in mind the reality of the United States remarks that empirical research has repeatedly proven secularization to be false. Another well-documented fact is that (monopoly) churches exhibit more liberal positions. In the explanation of these stylized facts, it is obviously important to consider how societies and individual attitudes toward religion evolve. But it is equally relevant to see churches as entities (organizations) that make decisions and evolve as well. Thus, both 'demand-side' and 'supply-side' elements concur to our understanding.

The contemporary seminal paper by Azzi and Ehrenberg (1975), fol-

\footnotetext{
${ }^{1}$ One should, however, distinguish between economics of religion and religious economics, which consists of looking at economics from a religious perspective: Kuran (1994) presents a discussion of these two different approaches.
} 
lowed by Ehrenberg (1977), and Sullivan (1985), created the starting point for the most recent literature on this issue. This literature is typically based on Becker's theory of household production. Individuals allocate their time and goods among religious and secular commodities so as to maximize lifetime and afterlife utility. Church attendance and religious participation aim at afterlife consumption. This assumption implies a strong restriction on the way religious commodities enter utility functions. The empirical support for this theory is mixed. Iannaccone (1998) concludes that it seems clear that the opportunity cost of time affects religious participation. It is less clear if afterlife expectations explain changes in religious behavior.

More recently, Iannaccone (1990, 1995a) and Durkin and Greeley (1991) have applied Becker's theory of human capital to discuss religious behavior as (rational or myopic) addiction rather than justifying participation on afterlife expectations. In his review of the literature, Iannaccone (1998) argues that the various predictions based on this theory have strong empirical support.

These two theories propose a rational explanation for religious preferences and participation. These are 'demand-side theories' in the sense that they suggest economic explanations for church attendance and affiliation, but they do not address the existence of churches per se.

Two main 'supply side' models have been developed to explain the existence of churches. Some scholars have posed that a church is a business firm that maximizes profits as Anderson, Ekelund, Hebert and Tollison (1992), Davidson and Ekelund (1997), and Ekelund, Hebert and Tollison (1989, 1992, 1996). They analyze the actions of the Roman Catholic church as a corporation aiming at monopolizing the religious market by regulating 
social norms (e.g. sin and redemption), eliminating competition (e.g. the Crusades), or controlling usury and exchange doctrines, scientific innovations or the marriage market. Yet another possibility in this context is to consider a more selfish objective function: a church maximizes the revenues from rent-seeking. ${ }^{2}$

This is not, however, the only approach that provides insight into the determinants of the religious 'supply side'. An alternative view is to pose that a church maximizes the welfare of its members as in Iannaccone (1988, 1992) and Zdeski and Zech (1992). Cassone and Marchese (1999) extensively discuss this approach. They argue that a church is an heterogenous club that pursues enlargement within a set of constraints. In particular, the members of the clergy are agents of the club. The need to align the interests of the clergy with those of the church constraints the growth of the church. A church is seen as a benevolent organization (i.e., it cares for the welfare of its members) but not their agents. Consequently, contributions to the church must be used to monitor and limit the discretion of the clergy.

Considerations of the existence of free-riders and monitoring costs can be found in Iannaccone (1988, 1992, 1994a) and Montgomery (1996a). Clubtheoretic models of high-cost sects and easygoing churches aim at integrating a large body of evidence. In particular, they argue that sects are smaller because monitoring costs increase with group size. Conversely, large churches have less demanding standards because monitoring is low. More liberal standards are a consequence of the fact that state churches are captured either by liberal clergy or by wealthy laypersons. In this paper, we uncover another explanation where location in the religious market is driven by external

\footnotetext{
${ }^{2}$ A similar view seems to be proposed in Hull and Bold (1989), Stonebraker (1993), and Schmidtchen and Mayer (1997).
} 
market forces rather than an internal lobbying game.

We make several contributions to the growing literature on the economics of religion. First, we explicitly introduce spatial location models into the economics of religion. Our analysis formalizes some informal arguments already present in the literature (Stark and Bainbridge 1985, 1987; Finke and Stark 1998, 1992). The specific nature of churches advises us to use a modified Hotelling model. Only with explicit recognition of strategic interaction can we understand reactions of existing churches to emerging sects.

Our second contribution is a new explanation for the fact that (monopoly) churches tend to be more liberal. Our explanation results from two observations: people may have a different attitude toward joining a more or less (religious) strict church than one prefers; and, churches care about aggregate welfare of their members. We offer an alternative to the "capture theory," where (monopoly) churches' choices are determined by individuals who prefer low religious strictness (Cassone and Marchese 1999).

Our third contribution is to show that a more liberal trend in main (monopoly) churches can be the outcome of a change from compulsory to voluntary membership. This complements the more usual explanation based in change of preferences.

Our fourth contribution is to provide an explanation for the relationship between religious strictness and membership. It is not clear that multidenominational societies where there is no dominant church have higher participation rather than mono-denominational societies. In our model, when there is more than one church, it ambiguous if the proportion of people participating in religion is higher than when there is only one church. The 
rationale is that a less conservative church faces competitive pressure by both more conservative and more liberal groups.

Our paper also provides alternative rationales for historical events and practices, for the relationship between church strictness and membership, and for the difficulty of the Catholic church becoming more liberal. Whereas the rationale for church doctrine (e.g. concerning sin and purgatory) provided by Ekelund, Hebert and Tollison (1996) is rent-seeking, we propose religious competition as an economic rationale for the observed changes.

This paper is a contribution to the theory of church location in the strictness space by applying the neoclassical theory of firm location. We propose a theory of church choice of strictness location, given religious preferences. We argue in this paper that neoclassical firm theory may also be of relevance in understanding some well-documented stylized facts such as the higher religious strictness of sects with respect to existing churches.

The basic ingredients we want to focus on are religious preferences of people and church's choice of religious strictness, given these preferences. To model this, a version of the Hotelling (1929) model of horizontal product differentiation seems well suited. The church's choice of strictness depends on the preferences of the population, that is, the church responds to wishes of the population: a stricter church emerges when the population is itself stricter on average. We also define a non-church by being a dummy firm with strictness zero. It constitutes our first departure from the usual models of product differentiation. We consider that costs of not having the mostpreferred variety of church strictness are asymmetric: the cost of belonging to a more strict church than the most preferred one is different from the one of joining a more lenient church. This feature is our second important 
departure from the standard Hotelling model.

The basic model is introduced in section 2 . In section 3 , we analyze the case of two churches. In section 4, we discuss the case of one church and one sect: we define a church as a leader and the sect as a follower, and show that the church becomes stricter when the sect threatens to or actually enters the market. The main conclusions are pointed out in section 5 .

\section{Basic model with one church}

Let us consider the usual Hotelling process of formation of a 'community' of customers around a seller, or in our case, of individuals around a church which provides a local public good.

The introduction of spatial-location models into the economics of religion finds support within the rational-choice sociologists of religion. In particular, Stark and Bainbridge $(1985,1987)$ and Finke and Stark (1988, 1992) have argued that various socio-demographic variables determine an individual's preferred type of religion; given the distribution of these preferences, denominations compete with each other over various 'niches' in the religious market. Our location model seems the 'natural' way of formalizing the Finke-Stark-Bainbridge paradigm.

An important assumption of our analysis is that preferences can be represented by a unidimensional variable that we have defined as religious strictness. In other words, the church's decision-making problem is solved by defining a position in that unidimensional space. It seems to us that such assumption is at least as compelling as the usual assumption in Political Science that parties choose a political platform from left to right. 
Religious strictness is obviously a variable that averages different items of a religious doctrine as shown in Iannaccone (1994a). However, we recognize that it excludes important factors that seem to be relevant to explain the demand for religious goods (and not correlated with religious strictness) like geographical location, 'local' versus 'national' markets, 'rural' versus 'urban' markets. $^{3}$

A second important assumption of our analysis, also common in Political Science, is that denominations move left or right at zero cost (we do not consider the possibility of 'inertia'). If the movement requires a denomination to add or subtract or alter doctrines while preserving consistency, change in denominational position seems far problematic than our model proposes.

Our analysis in this paper has been directly concerned with what we could call a rational theory of religious doctrine rather than management of a religious movement. In such perspective, religious strictness seems to be the relevant variable as an instrument of doctrine analysis. An empirical analysis of religious strictness can be found in Iannaccone (1994a). Considering several important variables as distinctiveness, church attendance, church contributions, membership in church-affiliated groups, biblical literalism or belief in afterlife, Iannaccone following previous work by sociologists proposes a reassuring ranking for US religious denominations from liberal denominations (Episcopal, Methodist, Presbyterian, and the United Church of Christ), followed by moderates (Evangelical Lutheran, Reformed Church, Disciples of Christ, American Baptist, and Catholic), and conservatives (Missouri Synod Lutheran, Southern Baptist, and Quaker) to ultra-

\footnotetext{
${ }^{3}$ Focusing on local markets, Finke and Stark $(1988,1992)$ push a non-standard claim that religious participation is higher in cities than rural areas because high population encourages more entry into the local religious market.
} 
conservative sects (Nazarene, Assemblies of God, Seventh Day Adventist, Mormon, and Jehovah's Witness). The location of individuals on the strictness line represents their own preferences on religion. ${ }^{4}$

Formally, individuals have a preference for religious strictness $x$ which takes a value from zero to one (maximal strictness). Religious strictness is distributed according to a density distribution function $g(x)$ with distribution function $G(x)$. The value of zero strictness is taken here as the choice of not having religion.

Consider the case of a church's single choice. This church is going to be located at $a$, that is, this church is going to choose a religious strictness given by $a$. The church provides a local public good which yields a gain $y$ to all those who decide to consume this good. ${ }^{5}$

An individual located at $x$ less than $a$ has a cost $t(a-x)$ to join such church and an individual located at $x$ greater than $a$ has a cost $t^{\prime}(x-a)$. We do not impose any particular order relation between $t$ and $t^{\prime}$. It may be the case that $t<t^{\prime}$; the cost of joining a church stricter than one favors is smaller than the cost of joining a church less strict than one favors. Alternatively, it may be the case that $t>t^{\prime}$; the cost of joining a church stricter than one favors is greater than the cost of joining a church less strict than one prefers. The consideration of asymmetric transport costs constitutes a first departure from the traditional Hotelling location model. ${ }^{6}$ According to this

\footnotetext{
${ }^{4}$ It is important to note the difference between preferences over church strictness and religious beliefs. A useful discussion can be found in Montgomery (1996b).

${ }^{5}$ As in the usual economic fashion, we have assumed that a religious denomination is a unitary actor with coherent preferences. As industrial economics has recognized the importance of organization theory and institutional economics, most decisions in religious organizations are the outcome of bargaining between various factions. See Montgomery (1996a) for a model in which the median voter determines a religion's location.

${ }^{6}$ On the use of asymmetric transport costs, although in a different context, see Nilssen (1997) and Nilssen and Sorgard (1998). Technically, our modeling approach to the cost
} 
characterization, an individual located to the right of $a$ has a payoff $y-$ $t^{\prime}(x-a)$, and individual located to the left of $a$ has a payoff $y-t(a-x)$.

The church acts as a benevolent planner, benevolent because it cares about the welfare of the 'insiders'; the objective function to be maximized is the sum of the gains minus the costs of those joining this church. Consequently, the welfare of 'outsiders' is ignored by the church. We consider that a church derives utility from individual welfare of its members. ${ }^{7}$ Note in passing that there are different interpretations consistent with our view. One is a rent-seeking view of the church. If we take contributions of individuals as a linear function of own-satisfaction, we have exactly the same analysis as under our assumption. Another interpretation is that the church cares about worship, and the 'insiders' are willing to pray more if their welfare is higher.

Other objective functions could be considered. A even more benevolent church would maximize the welfare of both 'insiders' and 'outsiders', independently of their decision concerning membership (more on this below). Such a church would care only about minimizing total transport costs. Although apparently appealing, this possible objective function has an implicit assumption: the church must value more some individuals when they choose the non-church than when they are affiliated with the church.

A third possibility is that a church simply maximizes the number of members independently of the value of the local public good they produce and the costs of joining the church borne by its members. ${ }^{8}$

function imposes discontinuity of the derivative at zero. This is not essential and the analysis can be performed without it, at the cost of exposition clarity.

${ }^{7}$ As supported by Iannaccone (1988).

${ }^{8}$ This last alternative seems to be the one with less empirical or anecdotal support. See Iannaccone (1998). 
An important assumption in our model is that membership and participation are equivalent. Individuals decide on which church to join, and not the allocation of time or wealth to religious activities as in the 'demand-side' theories. Consequently, we do not consider different degrees of participation.

Suppose that joining the church is compulsory; everyone in this population must join this church. In this case, the church objective coincides with total welfare because the 'insiders' are the entire population. The church objective function is:

$$
V=\int_{0}^{a}[y-t(a-x)] g(x) d x+\int_{a}^{1}\left[y-t^{\prime}(x-a)\right] g(x) d x
$$

One uses a linear transformation of $V$ derived from dividing it by $t+t^{\prime}$, allowing us to write the church's objective function as:

$$
V=\int_{0}^{a}[v-\alpha(a-x)] g(x) d x+\int_{a}^{1}[v-(1-\alpha)(x-a)] g(x) d x
$$

where $v=y /\left[t+t^{\prime}\right]$ and $\alpha=t /\left[t+t^{\prime}\right]$. It is assumed that $V$ is positively valued. A sufficient (but not necessary) condition for a positively valued objective function is obviously $v>1$ : the gain provided by the public good is greater than the cost of consuming it for all individuals. To avoid cluttering our analysis with too many technical conditions, we assume $g(x)$ to follow a uniform distribution of density one (that is, $g(x)=1$ ). For exposition purposes, we will keep the general notation throughout. ${ }^{9}$

The first-order condition is:

$$
V_{a}=-\int_{0}^{a} \alpha g(x) d x+\int_{a}^{1}(1-\alpha) g(x) d x=0
$$

\footnotetext{
${ }^{9}$ Most of the analysis can be extended to a general (continuous) distribution function, provided it meets some conditions. Ths assumption of the uniform distribution allows for closed form solutions. The more general characterization can be found at http://ppbarros.fe.unl.pt/papers.html, or upon request.
} 
The optimal location of this church is given by $G(a)=1-\alpha \cdot{ }^{10}$

Under the assumption that $t<(>) t^{\prime}$, we derive that $\alpha<(>) 1 / 2$, and so the optimal church location is at a point to the right (left) of the median. In the particular case $t=t^{\prime}$, the optimal location is the median. This is consistent with intuition: it locates closer to the customers who have a higher transport cost.

The optimal location is independent of the gain $v$ because it is the same for each member and all members of society must belong to the church. The same does not apply to the cost which varies across individuals.

The assumption of all individuals in a society joining a church can be relaxed. It may have not been the case in the past, but currently in the Western world, individuals are free to make up their own minds. In particular, they may choose to have no religion. Accordingly, let us introduce the concept of a non-church. Belonging to a non-church is equivalent to saying that individuals choose a religion with zero strictness. As a consequence, the strictness location of the non-church is zero by definition. This nonchurch produces a different local public good which also valued as $v$, and an individual located at $x$ joining this non-church bears a cost $t^{\prime} x .^{11}$ The fundamental difference between a church and a non-church is their location in terms of strictness, not the value of the local public good they produce.

An individual located to the right of $a$ always prefers the church to a non-church. However, the same does not apply to an individual located to the left of $a$. There is an indifferent individual $i$ such that any individual located to the left of $i$ prefers a non-church to a church located at $a$, where

\footnotetext{
${ }^{10}$ The second-order condition is trivially satisfied. It is straightforward to check that $V_{a a}=-1$ for the uniform distribution.

${ }^{11}$ The assumption of identical valuation $v$ is for exposition convenience only.
} 
the indifferent individual $i$ is defined by $i=\alpha a{ }^{12}$ The church objective function is:

$$
\begin{aligned}
V^{\prime} & =\int_{\alpha a}^{a}[v-\alpha(a-x)] g(x) d x+\int_{a}^{1}[v-(1-\alpha)(x-a)] g(x) d x \\
& =V-\int_{0}^{\alpha a}[v-\alpha(a-x)] g(x) d x
\end{aligned}
$$

The new term in the objective function of the church corresponds to the loss induced by the fact that joining the church is not compulsory. It can be seen as the maximal price that this church is willing to pay for a compulsory attendance statute. Thus, the church is not maximizing total welfare in society because the welfare of 'outsiders' is ignored (see discussion below).

The first-order condition of this problem is ${ }^{13}$ :

$$
V_{a}^{\prime}=V_{a}-\alpha[v-\alpha(1-\alpha) a] g(\alpha a)+\int_{0}^{\alpha a} \alpha g(x) d x=0
$$

Note that previously the interior solution was necessarily strictly positive. Now, this is not the case. Sufficient conditions for a strictly positive interior solution are $v<(1-\alpha) /(\alpha g(0))$ and $g^{\prime}(0) \geq 0$. The second condition is trivially satisfied by the uniform distribution. Suppose the gain from consuming the church's local public good is very large. As a consequence, the church should make sure that everyone joins it. Accordingly, the optimal location must be zero: the church makes a non-church in itself.

\footnotetext{
${ }^{12}$ It trivially follows from $v-\alpha(a-x)=v-(1-\alpha)(x-0)$.

${ }^{13}$ The properties of the uniform distribution ensure that the second-order condition is satisfied:

$$
V_{a a}^{\prime}=\alpha^{2}(2-\alpha)-1<0
$$
}


As long as $v$ is not very large, the optimal location is strictly to the right of the non-church. However, note from the first-order condition that it is not clear whether $G(a)<1-\alpha$ or not. If $v$ is small, it is the case that $G(a)>1-\alpha$. However, if $v$ is sufficiently large, the church moves left relative to the previous case of inexistence of a non-church, and $G(a)<1-\alpha$. On one hand, the introduction of a non-church implies that the church should become stricter to minimize its member costs: there is an incentive to move right, as the church loses members in the lowest tail of religious strictness. However, the presence of a non-church asserts that the number of believers decreases ceteris paribus: there is an incentive to move left to minimize the loss in the number of members choosing the non-church. The exact location of the church when a non-church is present will depend on the relative strength of these two opposing forces.

Note that the gain $v$ now plays a key role in the determination of the optimal location. This is so because the church and the non-church compete for those individuals who have preference for small strictness.

The explicit solution is:

$$
a^{* *}=\frac{1-\alpha-v \alpha}{(1-\alpha)(1+(1-\alpha) \alpha)}
$$

It is clear that the new optimal location can be to the left or right of $1-\alpha$, depending on $\alpha$ and $v$. It is easy to show that for $v>1$, the introduction of the non-church leads to a more liberal church.

Figure 1 illustrates the value of the optimal location in both cases of absence and presence of a non-church as a religious option. In Figure 1, $X=(1-\alpha) \alpha(2-\alpha), Y=1-\alpha$ and $Z=1 /(1+(1-\alpha) \alpha)$. It is plain to see that for low values of $v$, the optimal location $a^{* *}$ is above $1-\alpha$. However, for most values of $v$, a less conservative church will result. This feature of the 
Figure 1: Equilibrium values

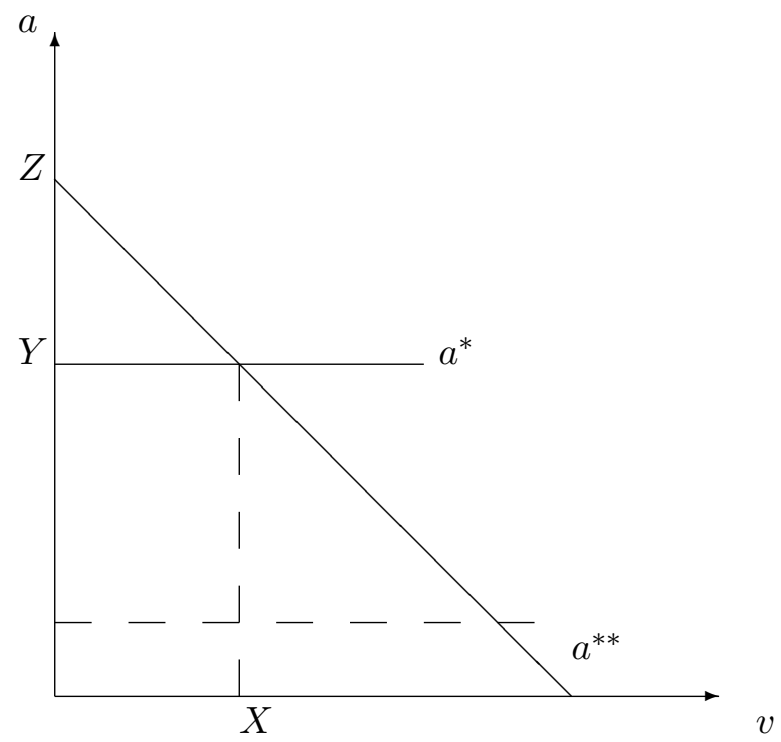

model explains one of the stylized facts about religion evolution, even if not one which is usually stressed: With religious freedom, meaning that people have the option of not belonging to a church, the main church becomes less conservative in their views in order to prevent some people from leaving the church. This effect occurs even if there is no change in preferences for religious strictness, which is the usual explanation for the more liberal trend in main churches. The mere change from compulsory membership in the church to voluntary membership is enough to produce this stylized fact.

This result has direct implication on the interpretation of the relationship between religious strictness and membership. In the scientific study of religion there has been some discussion on church strictness, church competition and the proportion of population without religious affiliation. ${ }^{14}$ Fol-

\footnotetext{
${ }^{14}$ See Martin (1978) and Lambert (1996).
} 
lowing these authors' analysis we can divide the Western world into six types of religious participation:

1. Mono-Catholic with high participation: Austria, Ireland, Italy, Luxembourg, Portugal, Spain.

2. Mono-Catholic with low participation: Belgium, France.

3. Mono-Protestant with high participation: Scotland.

4. Mono-Protestant with low participation: England and Wales [Anglicanism], Scandinavia [Lutheranism], Iceland.

5. Multi-denominational with high participation: Canada, USA.

6. Multi-denominational with low participation: the Netherlands, Germany, Switzerland.

Only Belgium, France and the Netherlands are considered 'laicized regions' where more than $25 \%$ declare without religion.

Observing that the Catholic Church is nowadays stricter than most of the Protestant denominations, we can say that, in a monopolistic context, it is more likely that we have high participation when a church is conservative rather than liberal. Such observation is supported by the model arguing that when there is high participation the church can afford to be conservative whereas when there is low participation the church must became liberal.

We have so far considered a church that maximizes benefits to its members. An alternative assumption on the objective function of the church would be to assume that churches maximize society's welfare. In our context, that amounts to minimize total transport costs. It is straightforward 
to compute the optimal strictness choice as $a=1 /(1+\alpha)$. This implies the church is more conservative, without ambiguity, in relation to our previous objective function. This is so because, since the church maximizes total welfare, it recognizes that individuals with preference for a very low level of religious strictness will be better off at the non-church choice than by joining the church. As they move away from the church, it can concentrate more on those individuals in society with higher preference for religion strictness. Therefore, it becomes more conservative. This intuition also makes clear why assuming a church that maximizes total welfare is less appealing than our maintained assumption. Under total welfare maximization, the church must value more some individuals when they choose the non-church than when they are affiliated with the church (for example, a person located at 0 is valued by the church as much as one with preference for the optimal strictness $a$ ). Accordingly, we retain maximization of members net benefits as the objective function of the church.

\section{Two churches}

Consider now the case where there are two churches, one located at $a$ (church A) and the other located at $b$ (church $\mathrm{B}$ ), where $b \geq a$, without loss of generality, in addition to the non-church located at zero. Both churches produce the same local public good, but differ in the strictness that they impose on their members.

An individual located at $j \in(a, b)$ is indifferent between joining a church located at $a$ and a church located at $b$, where $j=(1-\alpha) a+\alpha b$. 
Church A's objective function is:

$$
\begin{aligned}
V^{A} & =\int_{\alpha a}^{a}[v-\alpha(a-x)] g(x) d x+\int_{a}^{j}[v-(1-\alpha)(x-a)] g(x) d x \\
& =V^{\prime}-\int_{j}^{1}[v-(1-\alpha)(x-a)] g(x) d x
\end{aligned}
$$

Let us define $V^{\prime \prime}$ as $V$, where $a$ is replaced by $b$. Church B's objective function is:

$$
\begin{aligned}
V^{B} & =\int_{j}^{b}[v-\alpha(b-x)] g(x) d x+\int_{b}^{1}[v-(1-\alpha)(x-b)] g(x) d x \\
& =V^{\prime \prime}-\int_{0}^{j}[v-\alpha(b-x)] g(x) d x
\end{aligned}
$$

Churches compete in a Nash environment. Therefore, the solution to the location problem is derived by simultaneously solving $V_{a}^{A}=0$ and $V_{b}^{B}=0$.

Church A's first-order condition is:

$$
V_{a}^{A}=V_{a}^{\prime}+(1-\alpha)[v-(1-\alpha) \alpha(b-a)] g(j)-\int_{j}^{1}(1-\alpha) g(x) d x=0
$$

Similarly, church B's first-order condition is:

$$
V_{b}^{B}=V_{b}^{\prime \prime}-\alpha[v-\alpha(1-\alpha)(b-a)] g(j)+\int_{0}^{j} \alpha g(x) d x=0
$$

Solving $V_{a}^{A}=0$ and $V_{b}^{B}=0$, one gets best-response functions $\hat{a}(b)$ and $\hat{b}(a)$. Since second-order conditions are assumed to be satisfied, the signs of the reaction function are given by:

$$
\begin{gathered}
V_{a b}^{A}=(1-\alpha) \alpha^{2} g(j)+[v-\alpha(1-\alpha)(b-a)](1-\alpha) \alpha g^{\prime}(j)>0 \\
V_{b a}^{B}=\alpha(1-\alpha)^{2} g(j)-[v-\alpha(1-\alpha)(b-a)] \alpha(1-\alpha) g^{\prime}(j)>0
\end{gathered}
$$

where the signs follow from $g^{\prime}(x)=0$ for the uniform distribution. ${ }^{15}$

\footnotetext{
${ }^{15}$ For a more general characterization, see the appendix at http://ppbarros.fe.unl.pt/papers.html.
} 
Figure 2: Nash equilibrium

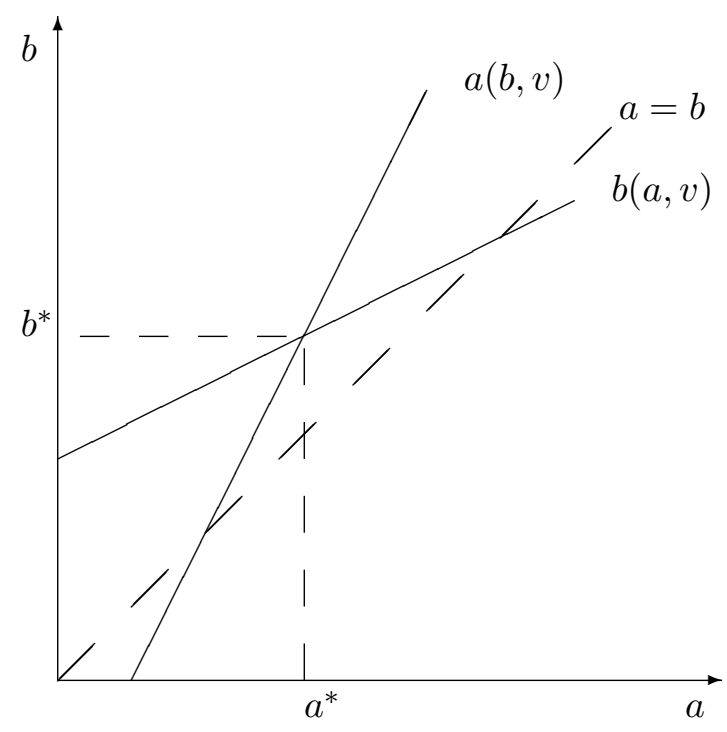

Solving the reaction functions for the equilibrium values of churches' locations, one has $a(v)$ and $b(v) .{ }^{16}$ Note that the slope of the reaction functions yields that $a$ and $b$ are strategic complements. Figure 2 illustrates the Nash equilibrium.

Consider now a marginal increase of $v$ :

$$
\begin{aligned}
V_{a v}^{A} & =-\alpha g(\alpha a)+(1-\alpha) g(j) \\
V_{b v}^{B} & =-\alpha g(j)<0
\end{aligned}
$$

Observing $V_{a v}^{A}$ and $V_{b v}^{B}$ we can distinguish two effects: first, there is an effect similar to that presented in section 2 - church $A$ becomes more

\footnotetext{
${ }^{16}$ The analysis performed holds at the margin. To ensure equilibrium, it is necessary that a church does not want to deviate, in a discrete way, to the other side, in strictness location, of the competing church. We assume here, in the vein of Austen-Smith (1996), that such deviations do not occur due to reputation effects. Otherwise, on technical grounds, it is necessary to characterize the conditions under which they are non-profitable.
} 
liberal because it is more costly to lose people to the non-church. Since locations are strategic complements, church $B$ also changes to a more liberal set of religious choices. At the same time, it is also more costly to lose people to the competitor, therefore there is a second effect by which the two churches converge. As a consequence, the more conservative denomination becomes more liberal but the same result does not apply to the more liberal denomination.

In terms of our previous discussion, we derive the implication that in multi-denominational societies where there is no dominant church, we cannot infer a lot from participation. As in our model, when there is more than one church (one being more conservative than the other), it is not clear if the proportion of the population joining the non-church at the Nash equilibrium is higher than when there is only one church. This observation seems to be consistent with empirical evidence. ${ }^{17}$

As to the Catholic Church, we can observe that it is usually more conservative in mono-Catholic countries with high participation (no competition from other denominations or the non-church) than in mono-Catholic countries with low participation (competition from the non-church) and multidenominational countries (competition from other denominations).

An interesting observation raised by the Catholic Church decisionmaking mechanism is the optimization problem faced by the Vatican. In terms of our model, the Vatican is presented in multiple markets (say, each country) facing potential or actual local competition. In other words, the Catholic Church cannot be liberal in one country and conservative in an-

\footnotetext{
${ }^{17}$ According to Hull and Bold (1998), usually an increase in the variety of products results in an increase in total market sales. The authors suggest that not necessarily in the religious market. Where product variety has significant costs, an increase in variety may reduce total market penetration.
} 
other. The consequence is that we should expect the Catholic Church to become more liberal if pressed by the non-church in the larger markets (say, larger countries) and more conservative if pressed by other denominations in the larger markets. Following the evidence presented in Martin (1978), we can suggest that secularization movements in Northern Europe press the Catholic Church to become more liberal but are offset by the growing (potential or actual) competition from stricter sects in the United States. ${ }^{18}$

\section{A church and a sect}

Our framework is also suitable to address the apparent contradiction between the secularization movement (in the sense that religion is declining) and empirical evidence on the recent trends in religion. According to Marler and Hadaway (1992), church authorities have faced in recent years (i) changes in denominational priorities; (ii) rising costs of building new and expanding old churches; (iii) increasingly specialized bureaucracy dealing with religious affairs. Simultaneously, the religious market become more competitive with new denominations. These entrants have an increasing average congregation size and grow faster than older incumbents. They seem to "plant churches" on areas of high population, high in-migration rates or unchurched people groups. Quite in contrast to the 'secularization theory', the religious market seems to be booming in the USA both in terms of supply (number of denominations available in the market) and demand (the number of individuals in the market).

According to Martin (1978), secularization in Western Europe, on the

\footnotetext{
${ }^{18}$ The fact that the Catholic Church offers various strict monastic orders and less strict lay movements eventually responds to this tension.
} 
other hand, has been affected by five key factors: (i) success or failure of Protestant reform; (ii) church's attitude to Enlightenment; (iii) church's attitude to democracy; (iv) the church as a mean of national identity and control of the state; (v) the impact of communism. On clear opposition with the 'secularization theory', Martin (1978) argues that even though the political influence of the different churches in Europe has been substantially reduced in this century, that is not say that religion has become less important.

Stark and Bainbridge (1985) claim that secularization is a myth and the religious market is essentially in steady state. Montgomery (1996a) has shown that cycles arise even though the aggregate distribution of religious preferences remains constant over time depending on key parameters characterizing denomination loyalty and strictness.

Our model proposes another explanation to solve this apparent contradiction between the 'secularization theory' or movement and the empirical evidence that the religious market is booming. When a denomination is monopolist, it is fairly conservative and a proportion of the population has no religious affiliation (joins the non-church). If some individuals change preferences by softening their religious strictness or the value of the public good provided by the church decreases, the monopolistic church becomes more liberal to keep them. Such move opens room for conservative entries in the market. In other words, when a group of people becomes less religious (an axiom of the 'secularization theory'), it is possible that the number of denominations available in the market increases. Moreover, it is not necessarily true that more individuals have no religious affiliation (precisely because the former monopolistic church became more liberal). The reform of the main Christian churches in Europe as a rational response to secularization on one hand, and increasing competition on the other hand is 
documented in Dobbelaere (1993). ${ }^{19}$

One of the most well-documented features about religion choices is the emergence of numerous sects, with the majority being created as a stricter dissidence from the religious option provided by the main church. In general, a church is defined as a specific branch of Christianity, ${ }^{20}$ supported by an establishment. A sect is an organized group holding stricter views on religion, usually one that has seceded from a larger body. Thus, entry considerations are of interest.

We define a church as a Stackelberg leader, and a sect as a follower. Therefore, church A and sect B do not play a Nash game, but a Stackelberg game. This is justified by the presumption that a church makes a stronger commitment to its strictness level than the sect. The ability of a sect to set and change strictness is higher than that of a church. For clarity of exposition, we will refer to the case of entry by a sect. ${ }^{21}$

We do not explicitly consider the role of entry costs. It is trivial to obtain that for zero entry costs one should see a proliferation of sects, while for sufficiently high entry costs entry is blockaded. Hence, there is a range of entry costs for which entry occurs. We also ignore the entry-deterrence effect that may be associated with such fixed costs. ${ }^{22}$ The outcome of entry games is dependent on the timing and sequencing of entry. We assume that

\footnotetext{
${ }^{19}$ Note that in the context of our model a church becoming more liberal is an endogenous decision. In other words, we do not need to have a shift of preferences to observe a given incumbent church to become more liberal.

${ }^{20}$ Of course, other examples based on different religions can be put forward.

${ }^{21}$ For the formal argument, nothing essential hinges upon this. The crucial element, and a reasonable one in our view, is that the entrant behaves as a follower with respect to strictness location decisions.

${ }^{22}$ The analysis would replicate the arguments pioneered by Dixit (1979), and by now extensively discussed in the industrial organization literature.
} 
only one entrant decides to enter. ${ }^{23}$

We study the case where the sect, sect B, considers an optimal location $b$ to the right of $a$; a sect is much stricter than a church. Sect $B$ 's optimization problem is similar to the one solved by church $B$ in the previous section; it takes $a$ as given. Church $A$ is a Stackelberg leader, and therefore anticipates the sect's location problem. The first-order condition of the optimization problem is:

$$
V_{a}^{A^{\prime}}=V_{a}^{A}+V_{b}^{A} \hat{b}_{a}=0
$$

where $V_{b}^{A}$ is $V^{A}$ with $b$ replaced by the sect's reaction function $\hat{b}(a)$.

It is clear from equation (5) that $V_{b}^{A}$ is positive; the stricter the sect is, the better it is for the church. We know already that, under our assumptions, $\hat{b}_{a}>0$. Therefore, it must be the case that $a$ is larger when the church is a Stackelberg leader rather than a Nash player. In the equilibrium location, church and sect are more conservative than the chosen locations of two churches.

In summary, the model reproduces the following stylized fact: in societies where the main church competes with another church, we expect the main church to be fairly liberal (United Kingdom, Scandinavia); in societies where the main church competes with sects, we expect the main church to be fairly conservative (Southern Europe, Brazil, United States), ceteris paribus.

Using the results presented previously, we can now address the following question: assuming that there is one church and a non-church, when and

\footnotetext{
${ }^{23}$ The number of entrants will depend on the level of entry fixed costs and on the specified rules - sequential vs. simultaneous entry. For example, under simultaneous entry decisions, too much entry may occur (Dixit and Shapiro, 1986).
} 
where should we expect entry by a sect in this market? That is, is the sect more liberal or stricter in religions terms than the main church?

The established denomination is located at $a^{* *}$ such that equation (4) is satisfied. From equation (9), we know that if the entrant moves to the right of $a^{* *}$, the established church will move in that direction. From equation (10), we know that if the entrant moves to the left of $a^{* *}$, the established church will move in that direction. The entrant acts like a follower, its decision being characterized by equation (11).

In a sense the solution to the problem depends on the relative value of the gain from consuming the local public good in terms of transport costs. If $v$ is very large, we know that $a^{* *}$ is close to (perhaps is) zero. An entrant with no entry costs will always find it profitable to enter to the right of the established church. For some range of parameter values, the model also reproduces the observed fact that sects (entrants) have fewer followers than the main church in equilibrium. If $v$ is sufficiently small and $\alpha$ is such that $a^{* *}$ is to the right of $1-\alpha$, then an entrant may find that entry to the left of $1-\alpha$ is profitable. The existence of a non-church affects not only the location of an established church, but also the entry game.

With no competition other than the non-church, a church will be more or less liberal, depending on the optimal solution to the trade-off between getting more members and satisfying the more conservative members. With competition of another church or sect, a church will become more conservative if the entrant is conservative, or more liberal if the entrant is liberal.

The above analysis provides an economic rationale to historical events and practices in the light of previous work by economists. Of course, historical events are the product of complex factors and our model is too simple to 
capture all the features. We propose competition (rather than rent-seeking) as an explanation for some historical facts. This new interpretation complements (rather than substitutes) previous literature. For example, the great East-West schism in the 11th century (mutual excommunication was imposed in 1054 and only abolished in 1965) can be seen as a consequence of different objective functions faced by Eastern and Western Catholic churches and competitive pressure. The Western Catholic Church was by then a monopolist, with monarchs and rulers accepting the role of the Pope as head of the church and Rome as religious capital. However, the Eastern Catholic Church was faced with stiff competition from Muslims and local Greek minor religious movements. Many of the local rulers and vassals of the Eastern Roman Empire were not Catholic and looked to Mecca or Baghdad as religious capitals. As a consequence, whereas Rome could embrace a conservative program since nobody really disputed the authority of the Pope, Constantinople could not accept such move and eventually decided to split. ${ }^{24}$

The distinctive change of Catholic doctrine concerning sin and its punishment can be seen in the context of a rational response to competition from the non-church and potential entrants, rather than simply rent-seeking as pointed out by Ekelund, Hebert and Tollison (1992). The origins of sins and its punishment are presented in the Old and New Testaments but its extension to almost all dimensions of man dates from the Early Middle Ages (in particular, with the development of canon law), achieving its highest peak with the Inquisition in the 16 th and 17 th centuries. As competition is almost eliminated from the early days through the Middle Ages, religious punishment of sins becomes more and more severe. Once the Catholic Church monopoly in the Western world is threaten and the authority of the Pope

\footnotetext{
${ }^{24}$ For example, the Eastern Church refused to stop allowing Greek priests to marry since that was allowed by other local Greek minor religious movements.
} 
is disputed, the concept of sin and its punishment evolves as a reaction to competitive pressure. For example, after the Enlightenment, when competition comes from what we have called a non-church, the Catholic doctrine opts for a less severe notion of sin and a much less severe doctrine allowing minor stricter Christian denominations to enter the market. ${ }^{25}$

Within the model we can also propose an interpretation for the recent growth of sects. A consequence of the secularization movement that we have discussed before is that the established church has become increasingly more liberal in order to compete with a non-church, i.e. to avoid people giving up on religion. The model tells us that an entry to the right of the established church (a stricter religious organization) has become more valuable. Thus, entry by sects seems more likely. As a consequence, the established church may have to halt its liberalization and even become conservative. In a sense, an established church faces pressure on both sides: there is more competition from the non-church because it becomes more attractive, given that a religious good is less valuable, and from a rival sect. In particular, our analysis suggests that there is a time pattern where more religious freedom leads first to a movement towards a more liberal stance, which in turn facilitates entry by sects that are more strict. Then, to cope with this entry, the main church may halt or even reverse the tendency towards a more liberal church. This description seems to fit real-world phenomena well, although a full rigorous test of the several trade-offs mentioned above is called for. ${ }^{26}$

\footnotetext{
${ }^{25}$ See Hull and Bold (1994) and Lipford, McCormick and Tollison (1995) for other economic theories of hell and preaching.

${ }^{26}$ In particular, we base our interpretation on a frictionless world, whereas in the real world adjustment costs are likely to limit the speed and path of adjustment.
} 


\section{Concluding remarks}

In this paper we propose an economic theory of church behavior given the religious preferences of the population. A church chooses its religious strictness to maximize its objective function taking into account the distribution of preferences across population, the value of the religious good it produces (a local public good) and the existence of a rival church, a sect or a nonchurch, that is, the possibility of individuals being not affiliated with a formal church. We have distinguished a church from a sect by arguing that a sect behaves like a Stackelberg follower. We show that the potential entry of sects induces an incumbent church to become more conservative whereas the possibility of opting for no religious affiliation has an ambiguous effect: on one hand, the church may become more liberal to compete with this non-church; on the other hand, it may become more conservative because its members are more conservative since the liberals leave the church.

Using an economic theory of church behavior, we discuss different issues involving religious behavior, namely the apparent contradiction between the so-called 'secularization theory' and the growth of religious movements; the decision-making trade-off faced by the Catholic Church and the rational response of remaining conservative.

We offer new explanations for some well-established stylized facts. Thus, future empirical research should confront the implications of our analysis with more traditional explanations.

\section{References}

1. Anderson, G. M.; Ekelund, R. B.; Hebert, R. F., and Tollison, R. D., 
1992, An Economic Interpretation of the Medieval Crusades, Journal of European Economic History; vol. 21, pages 339-63.

2. Austen-Smith, D., 1996, Electing Legislatures, in Collective DecisionMaking: Social Choice and Political Economy, edited by N. Schofield, Kluwer Academic Publishers: Boston, pp. 113-148.

3. Azzi, C., and Ehrenberg, R. G., 1975, Household Allocation of Time and Church Attendance, Journal of Political Economy, vol. 84, pages $27-56$.

4. Cassone, A., and Marchese, C., 1999, The Economics of Religious Indulgences, Journal of Institutional and Theoretical Economics, vol. 152, pages 429-442.

5. Davidson, A. B., and Ekelund, R. B., 1997, The Medieval Church and Rents from Marriage Market Regulations, Journal of Economic Behavior and Organization, vol. 32, 215-245.

6. Dixit, A., 1979, A Model of Duopoly Suggesting a Theory of Entry Barriers, Bell Journal of Economics and Management Science, vol. 10 , pages $20-32$.

7. Dixit, A., and Shapiro, C., 1986, Entry Dynamics with Mixed Strategies, in L. G. Thomas, ed., Strategic Planning, Lexington, Mass.: Lexington Books, pages 63-79.

8. Dobbelaere, K., 1993, Church Involvement and Secularization: Making Sense of the European Case, in Secularization, Rationalism and Sectarianism, edited by Barker, E.; Beckford, J. A., and Dobbelaere, K., Oxford, UK: Clarendon Press. 
9. Durkin, J. T. and Greeley, A., 1991, A Model of Religious Choice under Uncertainty, Rationality and Society, vol. 3, pages 178-196.

10. Ehrenberg, R. G., 1977, Household Allocation of Time and Religiosity: Replication and Extension, Journal of Political Economy, vol. 85, pages $415-423$.

11. Ekelund, R. B.; Hebert, R. F., and Tollison, R. D., 1989, An Economic Model of the Medieval Church: Usury as a Form of Rent Seeking, Journal of Law, Economics and Organization, vol. 5, pages 307-331.

12. Ekelund, R. B.; Hebert, R. F., and Tollison, R. D., 1992, The Economics of Sin and Redemption: Purgatory as a Market-Pull Innovation?, Journal of Economic Behavior and Organization,vol. 19, pages $1-15$.

13. Ekelund, R. B.; Hebert, R. F., and Tollison, R. D., 1996, Sacred Trust: The Medieval Church as an Economic Firm, Oxford, UK: Oxford University Press.

14. Finke, R., and Stark, R., 1988, Religious Economies and Sacred Canopies: Religious Mobilization in American Cities, 1906, American Sociological Review, vol. 53, pages 41-49.

15. Finke, R., and Stark, R., 1992, The Churching of America, 1776-1990: Winners and Losers in Our Religious Economy, New Brunswick, NJ: Rutgers University Press.

16. Hotelling, 1929, Stability in Competition, Economic Journal, vol. 39, pages $41-57$.

17. Hull, B. B., and Bold, F., 1989, Towards an Economic Theory of the 
Church, International Journal of Social Economics, vol. 16, pages $5-15$.

18. Hull, B. B., and Bold, F., 1994, Hell, Religion and Cultural Change, Journal of Institutional and Theoretical Economics, vol. 150, 447-464.

19. Hull, B. B., and Bold, F., 1998, Product Variety in Religious Markets, Review of Social Economics, vol. 56, 1-19.

20. Iannaccone, L. R., 1988, A Formal Model of Church and Sect, American Journal of Sociology, vol. 94 (Supplement), pages s241-s268.

21. Iannaccone, L. R., 1990, Religious Participation: a Human Capital Approach, Journal for the Scientific Study of Religion, vol. 29, pages 297-314.

22. Iannaccone, L. R., 1992, Sacrifice and Stigma: Reducing Free-Riding in Cults, Communes and Other Collectives, Journal of Political Economy, vol. 100, pages 271-292.

23. Iannaccone, L. R., 1994a, Why Strict Churches Are Strong, American Journal of Sociology, vol. 99, pages 1180-1211.

24. Iannaccone, L. R., 1994b, Progress in the Economics of Religion, Journal of Institutional and Theoretical Economics, vol. 150, pages 737744.

25. Iannaccone, L. R., 1995a, Risk, Rationality and Religious Portfolios, Economic Inquiry, vol. 38, pages 285-295.

26. Iannaccone, L. R., 1995b, Voodoo Economics? Reviewing the Rational Choice Approach to Religion, Journal for the Scientific Study of Religion, vol. 34, pages 76-88. 
27. Iannaccone, L. R., 1998, An Introduction to the Economics of Religion, Journal of Economic Literature, vol. 36, pages 1465-1495.

28. Kuran, T., 1994, Religious Economics and Economics of Religion, Journal of Institutional and Theoretical Economics, vol. 150, pages 769-775.

29. Lambert, Y., 1996, Denominational Systems and Religious State in the Countries of Western Europe, Research in the Social Scientific Study of Religion, vol. 7, pages 127-143.

30. Lipford, J. W.; McCormick, R. E., and Tollison, R. D., 1995, Preaching Matters, Journal of Economic Behavior and Organization, vol. 21, pages 235-250.

31. Marler, P. L., and Hadaway, C. K., 1992, New Church Development and Denominational Growth (1950-1983): Symptom or Cause?, Research in the Social Scientific Study of Religion, vol. 4, pages 29-72.

32. Martin, D., 1978, A General Theory of Secularization, Oxford, UK: Basil Blackwell.

33. Montgomery, J. D., 1996a, The Dynamics of the Religious Economy: Exit, Voice and Denominational Secularization, Rationality and Society, vol. 8, pages 83-110.

34. Montgomery, J. D., 1996b, Contemplations on the Economic Approach of Religious Behavior, American Economic Review, AEA Papers and Proceedings, vol. 86, pages 443-447.

35. Nilssen, T., 1997, Sequential Location when Transportation Costs are Asymmetric, Economic Letters, vol. 54, 191-201. 
36. Nilssen, T. and L. Sorgard, 1998, A Public Firm Challenged by Entry: Duplication or Diversity, Discussion Paper from Department of Economics, University of Oslo, n. 13/98.

37. Schlicht, E., 1997, The New Institutional Economics: Religion and Economics, Journal of Institutional and Theoretical Economics, vol. 153.

38. Schmidtchen, D., and Mayer, A., 1997, Established Clergy, Friars and the Pope: Some Institutional Economics of the Medieval Church, Journal of Institutional and Theoretical Economics, vol. 153, pages 122149.

39. Stark, R., and Bainbridge, W. S., 1985, The Future of Religion, Berkeley, US: University of California Press.

40. Stark, R., and Bainbridge, W. S., 1987, A Theory of Religion, Bern, Switzerland: Peter Lang.

41. Stonebraker, R. J., 1993, Optimal Church Size: the Bigger the Better?, Journal for the Scientific Study of Religion, vol. 32, pages 231-241.

42. Sullivan, D. H., 1985, Simultaneous Determination of Church Contributions and Church Attendance, Economic Inquiry, vol. 23, pages 309-320.

43. Zdeski, R. P., and Zech, Ch. E., 1992, Determinants of Contributions to Religious Organizations: Free-Riding and Other Factors, American Journal of Economics and Sociology, vol. 51, pages 459-472. 